\title{
"Cooperating for knowledge and innovation performance: the case of selected Central and Eastern European countries"
}

\begin{tabular}{|c|c|}
\hline AUTHORS & $\begin{array}{l}\text { Solomon Gyamfi } \text { https://orcid.org/0000-0002-3258-1095 } \\
\text { Jan Stejskal (D https://orcid.org/0000-0003-3015-8274 } \\
\text { [R http://www.researcherid.com/rid/S-7591-2017 }\end{array}$ \\
\hline ARTICLE INFO & $\begin{array}{l}\text { Solomon Gyamfi and Jan Stejskal (2020). Cooperating for knowledge and } \\
\text { innovation performance: the case of selected Central and Eastern European } \\
\text { countries. Problems and Perspectives in Management, 18(4), 264-274. } \\
\text { doi:10.21511/ppm.18(4).2020.22 }\end{array}$ \\
\hline DOI & http://dx.doi.org/10.21511/ppm.18(4).2020.22 \\
\hline RELEASED ON & Friday, 11 December 2020 \\
\hline RECEIVED ON & Monday, 15 June 2020 \\
\hline ACCEPTED ON & Wednesday, 25 November 2020 \\
\hline LICENSE & $\begin{array}{l}(\mathrm{cc}) \mathrm{EY} \\
\text { This work is licensed under a Creative Commons Attribution } 4.0 \text { International } \\
\text { License }\end{array}$ \\
\hline JOURNAL & "Problems and Perspectives in Management" \\
\hline ISSN PRINT & $1727-7051$ \\
\hline ISSN ONLINE & $1810-5467$ \\
\hline PUBLISHER & LLC "Consulting Publishing Company "Business Perspectives" \\
\hline FOUNDER & LLC "Consulting Publishing Company "Business Perspectives" \\
\hline$\sigma^{0}$ & $\begin{array}{l}\text { ニニ } \\
\text { 三ニ }\end{array}$ \\
\hline NUMBER OF REFERENCES & NUMBER OF FIGURES \\
\hline 56 & 4 \\
\hline
\end{tabular}

(c) The author(s) 2023. This publication is an open access article. 


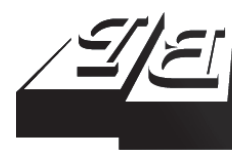

\section{BUSINESS PERSPECTIVES}

(O)

LLC "CPC "Business Perspectives" Hryhorii Skovoroda lane, 10, Sumy, 40022, Ukraine www.businessperspectives.org
Received on: $15^{\text {th }}$ of June, 2020 Accepted on: $25^{\text {th }}$ of November, 2020 Published on: $11^{\text {th }}$ of December, 2020

(C) Solomon Gyamfi, Jan Stejskal, 2020

Solomon Gyamfi, Ph.D. Candidate, Faculty of Economics and Administration, Institute of Economic Science, University of Pardubice, Czech Republic. (Corresponding author)

Jan Stejskal, Ph.D., Professor, Faculty of Economics and Administration, Institute of Economic Science, University of Pardubice, Czech Republic.

\title{
COOPERATING FOR KNOWLEDGE AND INNOVATION PERFORMANCE: THE CASE OF SELECTED CENTRAL AND EASTERN EUROPEAN COUNTRIES
}

\begin{abstract}
The open innovation concept thrives on knowledge and information flow; their sources for the current innovation performance of the selected Central and Eastern European (CEE) countries have since triggered research interest. This research aimed to explore the different sources of knowledge and information for innovation and the extent to which these different sources contribute to the innovation performance of small and medium-sized enterprises in some selected CEE countries. The study assesses the influence of different knowledge and information sources and their relationships in SMEs engaged in manufacturing activities for innovation performance in the selected CEE countries using structural equation modeling. Data were sourced from the anonymized European Community Innovation Survey (CIS, 2012). The results show that internal sources of information and knowledge from innovative internal activities highly influence SMEs' innovation performance in these CEE countries. Additionally, SMEs in the selected countries' sources of information and knowledge influence firm cooperation arrangements. The result is significant for SMEs and policymakers to ensure fostering information and knowledge sharing and support of creating valuable knowledge for innovation, most importantly, in the aftermath of financial and economic crisis.
\end{abstract}

Keywords

JEL Classification

\section{INTRODUCTION}

Innovation affects all spheres of human life in the globalized economy. Many studies and literature have found striking differences in Western and Eastern European countries' innovation performance in the European Union (Krammer, 2009; Hudec, 2015). The economies of CEE countries have been in transition since the Velvet revolution, which collapsed and broke the iron curtain of these countries' closed and inward-looking planned economies. In terms of innovation, the focus was on the close innovation paradigm until their accession into the European Union bloc. The then-planned societies then embarked on a transitional journey to adopt an open market economy three decades ago. An open economy needs open innovation for the knowledge economy to create and disseminate knowledge and information for innovation. The knowledge-based open economy has become the anchor for the innovation performance of some CEE countries. The open innovation model ascribes to information and knowledge flow as the crucial tenet for innovation performance. Therefore, the increasing competitiveness of the 
economies in some of the CEE countries reflects their pursuit of a different innovation policy mix directed at the modification of the then-planned economy into an open and knowledge-based one.

The recent boom in the economies of these countries is attributable to success in the utilization of innovation, of which small and medium-sized enterprises (SMEs) have played an important role. These SMEs' innovation performance is greatly dependent on mostly their innovative internal activities and through collaborative networks of the various economic actors in their business environment. This fosters SMEs' competitive advantage (Grover \& Kohli, 2015), creates capacity for people and nations to help alleviate shudders of globalization in the world's competitive economy (Malhotra et al., 2013, Gupta, 2016), and creates wealth and prosperity in the broader context (Tu et al., 2014).

However, in every transition, economic shock becomes inevitable. Fischer and Sahay (2000) assessed the first wave of shocks after a decade into these CEE countries' transition. They indicated that the decision surrounded the transition reform strategies regarding how the reform policies are sequentially implemented and the remedies for any economic shocks after that. It was not long, almost about two decades into the period that the second wave of shocks bedeviled the CEE countries' economies - the 2008 global economic recession. The transitional economies' adoption of the open market economy was complete before the 2008 economic crisis. During that time of economic crises, in intense globalization, associated with fierce competition, the pressing need to create novel knowledge mostly within SMEs was paramount. Unlike SMEs, large firms forcefully reinstitute new strategies to deal with such economic turbulence that helps manage innovation within the firm by soliciting internal knowledge sources for innovation. Moreover, Santoro et al. (2018) posit that firms would incur a higher cost of innovation in such a turbulent situation if resort to a close innovation model, may not be profitable and competitive. Within this idea, businesses tend to spread the cost by taking advantage of both internal and external sources of knowledge and information for innovation to beat down research and development costs as the model of open innovation demands (Halaskova \& Bednar, 2018).

Interestingly, most CEE countries' economies saw minimal shock during the financial and economic crisis where firms reduced expenditure to be sustainable (Kozena, Striteska, \& Svoboda, 2011). This brought a tremendous improvement in the aftermath of the crisis, which is worth scrutinizing the situation with the SMEs' sources of information and knowledge for innovation after the crisis (2010-2012). To the best of our knowledge, less scrutiny has been given to this area as far as sources of knowledge for SMEs' innovation in turbulent times is concerned in the CEE region.

\section{LITERATURE REVIEW}

\subsection{Knowledge, the necessity for innovation in the knowledge economy}

The knowledge economy thrives on intellectual capital with an emphasis on mainly knowledge-intensive activities. Jensen et al. (2007) describe comprehensively the different forms and modes of knowledge where they differentiate two modes of knowledge. Thus, knowledge is described as both codified from the science technology and innovation, and tacit knowledge of expertise is centered on learning by doing, using, and interacting. It has become the leading factor for recent econom- ic analysis of the knowledge economy. Codified knowledge countenances easily transfer from one person to another and firms to firms, whereas tacit knowledge lingers in the economic atmosphere as an innovative tidal wave waiting for direction for creative purposes. As a result, knowledge management becomes imperative for firms to utilize for innovation, most importantly, during crisis times. Hence, some scholars postulate the effect of regional influence on firm innovativeness (Stříteská, Zapletal, \& Jelínková, 2016; Fernández-Sastre \& Reyes-Vintimilla, 2020).

Therefore, the learning economy is a characteristic of interaction between firms and their operative environment through technical and intricate so- 
cial associations (Svetina \& Prodan, 2008). In their research, they found Eastern European countries to be less innovative than their Western counterparts. Perhaps, this clearly explains the widely acclaimed notion of economic, sociocultural, scientific, and technological differences and business attributes of different regional innovation systems manifested in the European Union. All these forms of knowledge are distributed manifolds.

The ability and the conducive environmental conditions necessary for sharing information or knowledge have been the main assumptions of the open innovation paradigm (Curley, 2016; Chesbrough, 2006). In line with the innovative system theory, open innovation involves both network and collaboration. Network with various economic system entities to co-create knowledge and share within the network for innovation purposes. The open innovation approach ascribes to these principles that firms acquire knowledge for innovation through collaboration activities, and innovation hinges on co-creating value, which becomes manifestly evident in the innovative ecosystem to explore new technologies (Vicente-Saez et al., 2020). During post-crisis times, firms may also collaborate in various research activities to avoid lagging in the race to survive (Tsouri, 2019). Hence, in as much as firms seek internal research and development for information and knowledge for innovation, they also pursue external sources by cooperating with international and national entities such as higher education institutions, suppliers, customers, and public and private research institutes. However, Tsouri (2019) posits in her paper that firms collaborate with trusted actors in times of crisis. This is because firms look inward for knowledge transfer during crisis times. However, firms tend to grow the knowledge transfer networks within their regions and become glued to global pipelines and bring in external knowledge from other sources.

Indeed, for firm's innovation performance, $R \& D$ activities have become the overarching means for large firms to innovate for competitive advantage through increasing R\&D investment for the internal capabilities of the firm, which was the notion of the linear innovation model. However, it failed to propose a solution for the SMEs in the society, which play a key role in employment provision and contributing to regional competitiveness and development (Klasova, 2018). Moreover, some SMEs have managed to sustain innovation, which has seen worldwide scrutiny by many scholars and government policies formulated to enhance their innovation activities. It is imperative to indicate that whereas information and knowledge in large firms' flow within the interaction among and between the firm's functional units and teams, SMEs mainly rely on external knowledge sources (Camagni \& Capello, 2017).

Firms obtain new knowledge from many internal and external sources to continuously generate innovation and maintain competitive superiority (Gyamfi \& Stejskal, 2019). Recent occurrences and socio-economic revolution influenced by globalization have spread transnational competitiveness. The recent inventions and technological breakthroughs require the intensive use of information, computers, and technologies for manufacturing companies and SMEs alike. Knowledge has since become a scarce resource, which has led to alteration of firms' current organizational behavior in their recruitment of talented and well-qualified employees.

\subsection{Internal and external knowledge sources and cooperation for innovation}

Firms tend to internally generate and disseminate knowledge within the organization for innovation; on the other hand, firms need internal capacity and knowledge external to the firm for innovation. There is a general dichotomous source of firm knowledge and information for innovation (Santoro et al., 2020; Rosdi et al., 2020). Acquiring knowledge internally involves in-house R\&D activities through learning and constant improvement in organizational processes. For example, recruiting employees with adequate skills constitute an important source of novel knowledge (Basit \& Medase, 2019).

Additionally, firms' internal training programs and continuous improvement through further education develop and enhance firms' internal knowledge base. However, when knowledge within a firm is not adequate for the firm's innovation activities, firms can acquire knowledge through 
collaboration networks involving other firms, customers, and suppliers (Prokop et al., 2019) that may manifest in either formal or informal relationships and networks. Besides, through a strategic alliance between public and private institutions such as universities, research institutions within the firm's location, firms may form partnerships with other entities outside the home country (Svetina \& Prodan, 2008; Merickova et al., 2020). However, when the internal absorptive capacity is not developed, external knowledge may not be useful for ensuring innovation (Gyamfi \& Stejskal, 2019a). Hence, there is a need for territorial innovation patterns with external knowledge linkages (Srholec \& Žížalová, 2014; Liu, 2018; Trippl et al., 2018; Tödtling \& Trippl, 2016; Stejskal et al., 2018; Zdražil \& Kozuń-Cieślak, 2017). SMEs' open innovation involves external networks that are not structured and based on informal settings that enable the acquisition of new knowledge (Bigliardi \& Galati, 2016) for innovation, even though mixed empirical results exist about this phenomenon.

In recent times, theories and research on innovation have found inter-firm collaboration as a common means by which many firms gain external knowledge for innovation (Kotkova \& Prokop, 2020). Since innovation activities mostly involve collaboration between producers and customers, especially of products, interaction becomes inevitable and mainly informal, but other organizations have created formal means, which may take the form of exchange of technical knowledge; at the same time, it offers important information about relevant market trajectories and specific modern trends.

The supply chain involving suppliers is also an essential source of external knowledge for the firm understanding of the production process, logistics, and other functions of the innovation process (De Zubielqui et al., 2019; Von Delft et al., 2019). Thus, the firm's cooperation with other firms may also involve collaborative activities connecting business partners and competitors (Mukherjee et al., 2019). Both horizontal and vertical inter-firm cooperative arrangements have provided important sources of external knowledge and information to the firm for innovation performance. Evidence from CEE regions suggests that firm sources of knowledge for innovation mainly emanate from the firm in-house R\&D activities in knowledge-intensive firms (Radosevic et al., 2008).

Recent studies have reviewed SMEs collaboration and innovation performance. SMEs form both vertical and horizontal collaborations with suppliers, customers, and partners within the enterprise group and competitors, respectively (MacGregor, 2004). This cooperation mostly takes both informal and formal forms, and the aim has been to create a pool of resources for conducting R\&D into the use of novel technological inventions (Braga et al., 2016; Radicic et al., 2020) for firm's innovation activities and performance. This helps improve the innovation ecosystem, especially in the aftermath of an economic recession, in as much as many studies have looked at the various effect of firm sources for information and knowledge for innovation performance and cooperation as a significant means which most SMEs use for acquiring external knowledge (for example, Prokop \& Stejskal, 2019 whose paper looked at the German manufacturing SMEs).

However, less attention has been given to SMEs in the so-called traditional manufacturing companies in the CEE countries, which motivates this research.

The research seeks to examine the various sources of knowledge and information and the extent to which these different sources contribute to SMEs' innovation performance in some selected CEE countries. This study contributes to the cooperation of SMEs' innovation literature and offers constructive recommendations for policymakers in the selected CEE countries.

Given the mentioned above, the propositions and hypotheses can be formulated as follows:

Proposition 1. Firms in the post-crisis period tend to develop internal knowledge capacity than sourcing knowledge from external sources.

H1: SMEs' internal innovative activities significantly and directly influence innovation performance.

Proposition 2. Sources of information and knowledge for firms' influence innovation performance. 
H2: SMEs' sources for information and knowledge significantly influence their innovation performance.

Proposition 3. Firms engage in collaboration as a means to sourcing external knowledge for innovation performance.

H3: SMEs' cooperation arrangements influence their internal innovation activities.

\section{RESEARCH METHODOLOGY AND DATA}

This section of the paper deliberates on sampling and the source of data collection. Furthermore, it delineates the method for data analyses, operationalization, fitness of model, and reliability and validity measures. The research collected data from the anonymized European Union Community Innovation Survey (CIS) 2010-2012 on SMEs engaged in manufacturing activities in some selected CEE countries, which include Slovenia, Slovakia, Lithuania, and the Czech Republic. The anonymized data from CIS consist of questionnaires sent out to firms, both large and small or medium-sized in the participating European countries, with a keen objective to gather microdata at the firm level to analyze firm innovation performance and engagement in innovation activities of the firm, sources of information, and collaborative activities. however, they were used to assess the SMEs' immediate mitigation strategies in the selected countries as to how these firms sourced information and knowledge for innovation performance. Partial Least Squared Structural Equation Modeling (PLS-SEM) was used for the empirical analysis (Hair et al., 2017; Henseler et al., 2016). PLS-SEM leans on multi-regression analysis to provide scores for the latent variable measured by one or more indicators. It can estimate with small sample size issues measuring very complex models with many latent and manifest variables. The PLS-SEM is given by equation (1) (Zawojska, 2010).

$$
z k=\beta_{0}^{(k)}+\sum \beta_{i}^{(k)} z_{i}+v_{k},
$$

where $z k$ depicts the explained variable in this study, innovation performance, $\beta_{0}^{(k)}$ denotes the constant term, $\sum \beta_{i}^{(k)}$ represents the regression coefficient, $v_{k}$ connotes residual term.

The innovation performance of manufacturing SMEs in the selected CEE countries was measured concerning the objective of this research by assessing the cooperation arrangements for their internal and external innovation activities, and various sources of information and knowledge for innovation. Figure 1 illustrates the conceptual framework for the empirical analysis.

The figure depicts the linkages between SMEs' cooperation arrangements and sources of information for internal innovation activities, which then

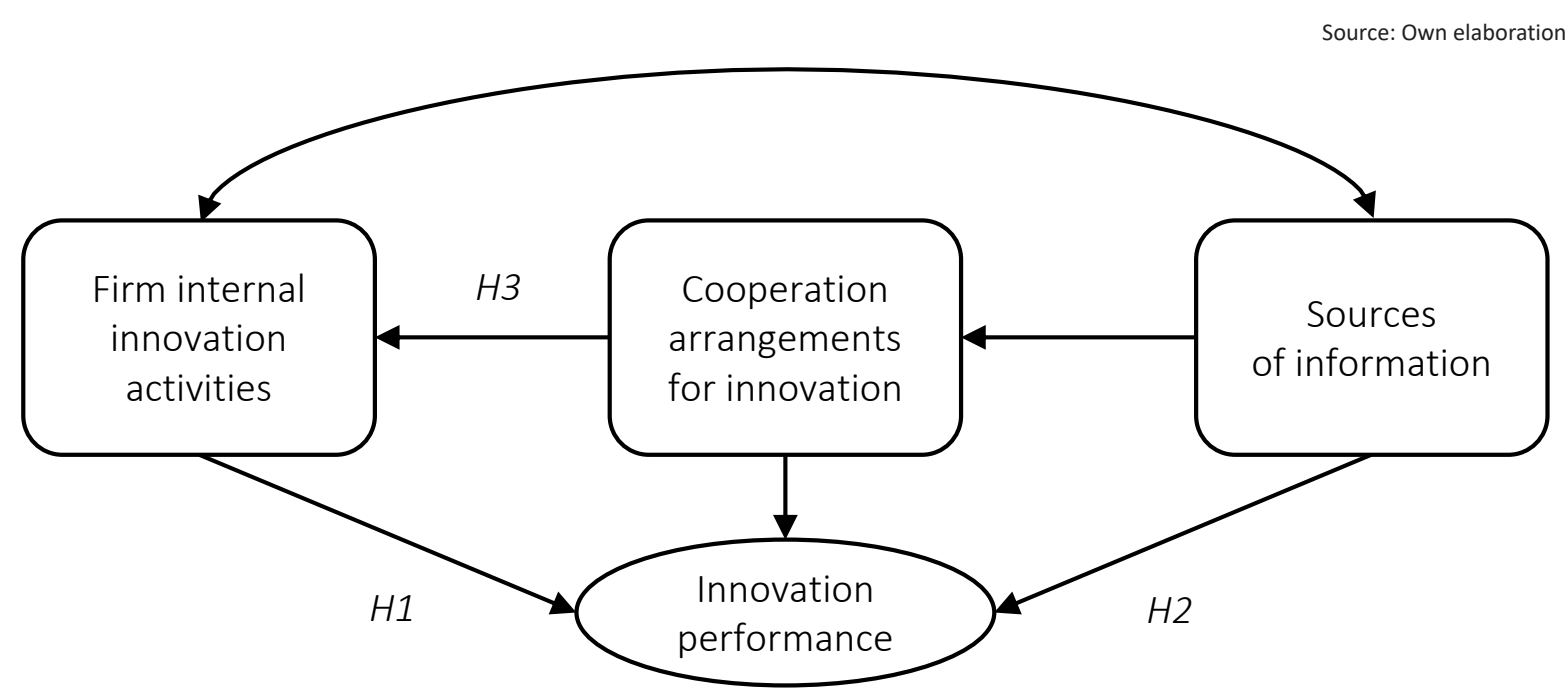

Figure 1. Research analytical framework 
influences the enterprises' overall innovation performance in the selected countries. The dependent variable and the independent variables have been measured by the CIS survey's dichotomous response and summarized in Table 1.

Table 1. Description of dependent and independent variables

\begin{tabular}{|c|c|c|}
\hline Variable & Description & Author(s) \\
\hline \multicolumn{3}{|c|}{ Dependent variables } \\
\hline INPDGD & $\begin{array}{l}\text { Introduced onto the market } \\
\text { new or significantly improved } \\
\text { goods }\end{array}$ & \multirow[t]{2}{*}{ Toth et al. (2018) } \\
\hline NEWMKT & $\begin{array}{l}\text { Product innovation new to the } \\
\text { market }\end{array}$ & \\
\hline \multicolumn{3}{|c|}{ Independent variables } \\
\hline CO41 & $\begin{array}{l}\text { Cooperation arrangements } \\
\text { with other firms, national }\end{array}$ & \multirow{5}{*}{$\begin{array}{l}\text { Christensen et al. } \\
\text { (2019), Prokop et } \\
\text { al. (2019), Odei and } \\
\text { Stejskal (2019) }\end{array}$} \\
\hline CO51 & $\begin{array}{l}\text { Cooperation arrangements } \\
\text { with consultants, commercial } \\
\text { labs, private R\&D institutions }\end{array}$ & \\
\hline Co61 & $\begin{array}{l}\text { Cooperation arrangements } \\
\text { with universities }\end{array}$ & \\
\hline CO71 & $\begin{array}{l}\text { Cooperation arrangements } \\
\text { with government or public } \\
\text { research institute }\end{array}$ & \\
\hline CO311 & $\begin{array}{l}\text { Cooperation arrangements } \\
\text { with client or customers }\end{array}$ & \\
\hline RRDEX & Extramural R\&D & \multirow{3}{*}{ Moura et al. (2019) } \\
\hline ROEK & External knowledge acquisition & \\
\hline RTR & Training for innovation & \\
\hline SENGTG & $\begin{array}{l}\text { Info. from within the enterprise } \\
\text { group }\end{array}$ & \multirow{6}{*}{$\begin{array}{l}\text { Odei and Stejskal } \\
\text { (2018), Prokop and } \\
\text { Stejskal (2019) }\end{array}$} \\
\hline SSUP & $\begin{array}{l}\text { Info. from suppliers or } \\
\text { customers }\end{array}$ & \\
\hline SCOM & $\begin{array}{l}\text { Information from other } \\
\text { competitors within the same } \\
\text { industry }\end{array}$ & \\
\hline SINS & $\begin{array}{l}\text { Info. from consultants or } \\
\text { private and public R\&D } \\
\text { institutions }\end{array}$ & \\
\hline SUNI & $\begin{array}{l}\text { Info. from higher education } \\
\text { institutions }\end{array}$ & \\
\hline SGMT & $\begin{array}{l}\text { Info. from government and } \\
\text { public research institutes }\end{array}$ & \\
\hline
\end{tabular}

\subsection{Model evaluation}

The paper measured collinearity using the Variance Inflation Factor (VIF). The model showed no multicollinearity issues, with all the variables showing values of $<5$ (Hair et al., 2017a).

Cronbach's alpha of 0.81 (cooperation arrangements), 0.72 (innovative internal activities), and 0.81 (sources of information) show a substantial internal consistency of variables operationalized to measure constructs used in the model. The variance explained for the innovation performance was $37 \%$. Table 2 shows the construct reliability and validity.

Table 2. Summary of the construct reliability and validity

Source: Own calculations

\begin{tabular}{|c|c|c|c|c|}
\hline Construct & Variables & $\begin{array}{c}\text { Outer } \\
\text { loadings }\end{array}$ & AVE & $\begin{array}{l}\text { Cronbach's } \\
\text { alpha }\end{array}$ \\
\hline \multirow{2}{*}{$\begin{array}{l}\text { Innovation } \\
\text { performance }\end{array}$} & INPDGD & 0.908 & \multirow{2}{*}{0.793} & \multirow{2}{*}{0.741} \\
\hline & NEWMKT & 0.873 & & \\
\hline \multirow{5}{*}{$\begin{array}{l}\text { Cooperation } \\
\text { arrangements for } \\
\text { innovation }\end{array}$} & CO41 & 0.723 & \multirow{5}{*}{0.568} & \multirow{5}{*}{0.809} \\
\hline & CO51 & 0.727 & & \\
\hline & CO61 & 0.733 & & \\
\hline & CO71 & 0.741 & & \\
\hline & C0311 & 0.836 & & \\
\hline \multirow{5}{*}{$\begin{array}{l}\text { Sources of } \\
\text { information and } \\
\text { knowledge }\end{array}$} & SUNI & 0.624 & \multirow{5}{*}{0.570} & \multirow{5}{*}{0.808} \\
\hline & SINS & 0.731 & & \\
\hline & SCOM & 0.783 & & \\
\hline & SENTG & 0.796 & & \\
\hline & SSUP & 0.822 & & \\
\hline \multirow{3}{*}{$\begin{array}{l}\text { Innovative internal } \\
\text { activities }\end{array}$} & ROEK & 0.790 & \multirow{3}{*}{0.637} & \multirow{3}{*}{0.716} \\
\hline & RRDEX & 0.792 & & \\
\hline & RTR & 0.813 & & \\
\hline
\end{tabular}

The factor analysis shows outer loadings above 0.4 and significant. The model also estimated Cronbach's alpha above 0.74 , which signals strong internal consistency of the two variables operationalized to measure the dependent construct. The confirmatory factor analysis showed that the three-factor structure fits the data, with the following model fit indices (see Table 3).

Table 3. Goodness-of-fit

Source: Own calculation based on Henseler et al. (2016a).

\begin{tabular}{l|c}
\hline \multicolumn{1}{c|}{ Model fit indices } & Value \\
\hline Chi-squared & 235.303 \\
\hline SRMR & 0.09 \\
\hline NFI & 0.63 \\
\hline d_ULS & 1.003 \\
\hline d_G & 0.49 \\
\hline
\end{tabular}

\section{RESULTS}

For innovation performance or novel innovation new to the market, it is appropriate that a company creates and maintains good cooperative arrangements with other entities. Collaboration with other entities has proven to be an effective 
means for firm knowledge acquisition, leading to intense firm innovation performance. Through firm's cooperation arrangements with universities, research institutes, customers, and suppliers, both internal and external knowledge needed for firms' innovation activities are acquired, enhancing competitiveness.

The structural equation modeling result shows a strong influence of the firm's internal innovative activities on innovation performance with a significant, positive, and high path coefficient of 0.39 . This is a signal that SMEs' intramural research and innovative activities largely influence innovation performance in the post-crisis period, which supports $H 1$ that SMEs' internal innovative activities significantly and directly influence innovation performance.

Regarding sources of information for firm's innovation performance, the construct showed a moderate but positive significance path coefficient of 0.22 . This indicates that sources of information and knowledge from competitors within the enterprise group; suppliers of equipment and materials; consultant and private research and development institutes; and information from universities and other higher education institutions enhance firm's innovation performance. This finding supports $\mathrm{H} 2$ that SMEs' sources of information for innovation activities significantly influence innovation performance.

Regarding firm's cooperative arrangement for innovation, the model shows a positive influence on innovation performance; however, the path coefficient of 0.069 means less influence. This means that most Central and Eastern European SMEs lack cooperation for innovation, especially in the aftermath of a major financial and economic crisis. The model generally predicts no statistical signifi- cance of cooperation arrangements for innovation performance with a $p$-value of 0.417 , as shown in Table 4.

For the firm's internal innovative activities, SMEs in the selected CEE countries moderately seek information and knowledge for innovation performance through the cooperation arrangements of the firm. With a path coefficient of 0.298 from Table 4, H3 is confirmed. Additionally, the firm's type of cooperation arrangements is influenced by the sources of information and knowledge for innovation performance, which presupposes that sources of information and knowledge for firm innovation performance significantly influence cooperative arrangement.

\section{DISCUSSION}

The 2008 financial crisis affected the European Union countries' innovation policies heavily but mostly in the CEE countries mainly because the national innovation systems were in transition, hence, were susceptible to economic shocks. A European Commission sanctioned research on the influence of the financial crisis on research and innovation found that most CEE countries' research and innovation budget suffered (Izsak et al., 2015), and additionally struggled to mobilize human resources for research and innovation activities, more so, others had difficulties in retaining skilled labor. To mitigate this, most EU economies introduced a novel policy mix to facilitate research and development in innovation. In the CEE countries, specifically, policies aimed at supporting research and development in firms and the judicious use of EU structural funds to stimulate innovation performance were observed (Izsak \& Radošević, 2017). Even though, the research found that, particularly for the Czech Republic,

Table 4. PLS-SEM path coefficient

Source: Own calculation.

\begin{tabular}{|c|c|c|c|}
\hline Construct path & Loading & T-stat. & $p$-value \\
\hline Sources of information and knowledge _Cooperation for innovation & 0.221 & 1.934 & $0.054 *$ \\
\hline Sources of information and knowledge _- Innovative internal activities & 0.386 & 5.138 & $0.000 * * *$ \\
\hline Sources of information and knowledge__Innovation performance & 0.564 & 7.876 & $0.000 * * *$ \\
\hline Internal innovative activities _Innovation performance & 0.399 & 3.158 & $0.000 * * *$ \\
\hline Cooperation for innovation _- Innovative internal activities & 0.298 & 4.607 & $0.002 * * *$ \\
\hline Cooperation for innovation__Innovation performance & 0.069 & 0.812 & 0.417 \\
\hline
\end{tabular}

Note: Legend: * significant at $p<0.05, * * *$ significant at $p<0.001$. 
the competitiveness of the businesses that received support enabled an increase of the production capacity and efficiency and a growing number of customers. However, the aftermath of the financial crisis saw some CEE countries recording less impact on cooperation between the industry and knowledge-intensive organizations but, most importantly, traditional manufacturing or transport companies (Strelcova \& Janasova, 2018).

This study has shown that the cooperation arrangements of SMEs have no statistically significant influence on innovation performance. This contradicts the flagship policies of the EU agenda 2020, which underscores the importance of close collaboration as a necessity towards the economic crisis recovery. In corroboration with this finding, Prokop et al. (2019) found this to be still at play eight years after the financial crises and the insignificant impact of firm cooperation arrangements on innovation performance. Even though the research found a significant influence of collabora- tion on the manufacturing SMEs' internal innovation activities, such cooperation arrangements do not lead to innovation performance.

More so, sources of information and knowledge have a statistically significant effect on SMEs' cooperation arrangements for innovation, internal innovation activities, and SMEs' innovation performance. Firms cooperate mainly for external knowledge and information, which supports the findings of Stejskal et al. (2018) and De Silva et al. (2018). The result also showed that SMEs in the selected CEE countries' intramural R\&D activities significantly affect innovation performance. A strong internal research capability of a firm is a signal of absorptive capacity, which allows for effective utilization of external sources of knowledge and information. As found in Svetina and Prodan (2008), developing know-how has been an internal activity of firm innovation. This is obvious in most post-communist countries' innovation strategies despite the insurgence of the open innovation policy.

\section{CONCLUSION}

In this era of intense globalization and competition, firms cannot solely rely on their internal knowledge generational capacity but rather look for cooperation and networks that would provide more diverse sources of information and knowledge for innovation activities. The paper aimed to explore the different sources of knowledge and information for innovation and how these different sources contribute to the innovation performance of manufacturing SMEs in some selected CEE countries.

From the analysis, the research found that internally generated sources of information and knowledge are employed most for firm innovation activities in CEE SMEs; however, they do incorporate other sources of information for innovation performance, such as through cooperation arrangements. This finding corroborates that of Hall (2008) that firms need to integrate the internal learning process with knowledge acquired beyond the firm's innovation performance environment. More so, it has been revealed that SMEs cooperation for innovation is dependent on the kind of information and knowledge sources of the firm. This enables policymakers to create and nurture an effective and efficient innovative environment to support SMEs' active collaboration activities for innovation (Aydalot \& Keeble, 2018), most especially in times of economic crisis.

However, firms also need to create and support cooperation with different partners in the worldwide economic environment to improve innovativeness, especially since Radosevic (2011) postulates that most knowledge-intensive firms in six selected CEE countries to be what he describes as knowledge-localizers as they adapt global knowledge to support local market needs rather than being global knowledge-creators. Additionally, the results indicated no statistical significance of cooperation arrangements for innovation performance. This result, therefore, supports the findings of Prokop et al. (2019) in their analysis of cooperation in the innovation of small CEE countries that the selected economies' innovation is characterized by a low tendency to collaborate within the innovation ecosystem, which stems from a lack of trust and lacking proper facilitation policies from the governments. 
Despite the call for firms, especially SMEs, to embrace collaboration for innovation due to the complexity and increasing cost of internal knowledge creation, the findings showed that SMEs in the selected CEE countries are oblivious of the benefits of cooperation. Engaging in mainly internal generation of knowledge for innovation was found not to influence firms' innovation performance in a region because of the lock-in effect firms experience, which hinders competitiveness because these firms cannot produce the products that are new to the market.

\section{AUTHOR CONTRIBUTIONS}

Conceptualization: Solomon Gyamfi.

Data curation: Solomon Gyamfi.

Formal analysis: Jan Stejskal.

Funding acquisition: Jan Stejskal.

Investigation: Solomon Gyamfi.

Methodology: Jan Stejskal.

Project administration: Solomon Gyamfi.

Resources: Solomon Gyamfi.

Software: Solomon Gyamfi.

Supervision: Jan Stejskal.

Writing - original draft: Solomon Gyamfi.

Writing - review \& editing: Jan Stejskal.

\section{ACKNOWLEDGMENT}

This work was supported by a grant provided by the scientific research project of the Czech Sciences Foundation Grant No. 20-03037S.

\section{REFERENCES}

1. Atkinson, R., \& Wial, H. (2008).

Boosting productivity, innovation, and growth through a National Innovation Foundation (8 p.). Washington: Brookings Institution. Retrieved from http://www.itif.org/ files/NIF.pdf

2. Aydalot, P., \& Keeble, D. (Eds.) (2018). High technology industry and innovative environments: the European experience (254 p.). London: Routledge. https://doi. org/10.4324/9781315149769

3. Basit, S. A., \& Medase, K. (2019). The diversity of knowledge sources and its impact on firm-level innovation. European Journal of Innovation Management, 22(4), 681-714. https://doi.org/10.1108/EJIM-102018-0232

4. Bigliardi, B., \& Galati, F. (2016). Which factors hinder the adoption of open innovation in SMEs? Technology Analysis \& Strategic
Management, 28(8), 869-885. https://doi.org/10.1080/09537325.2 016.1180353

5. Braga, V., Gonçalves, A., \& Braga, A. (2016). The Portuguese textile industry business cooperation: informal relationships for international entry. The Romanian Review Precision Mechanics, Optics \& Mechatronics, 49, 52-60. Retrieved from https://www.incdmtm.ro/editura/revista/index.php?pag=show articol\&id_articol=805\&lang=en

6. Camagni, R., \& Capello, R. (2017). The role of inter-SME networking and links in innovative high technology milieux. In D. Keeble \& F. Wilkinson (Eds.), High-technology clusters, networking and collective learning in Europe (pp. 118-155). London: Routledge. Retrieved from https://www.taylorfrancis.com/ books/e/9781315188904/chapters/10.4324/9781315188904-5
7. Chesbrough, H. (2006). The era of open innovation. Managing Innovation and Change, 127(3), 34-41.

8. Christensen, J., Hain, D., \& Nogueira, L. (2019). Joining forces: collaboration patterns and performance of renewable energy innovators. Small Business Economics, 52(4), 793-814. https://doi.org/10.1007/s11187-0179932-0

9. Curley, M. (2016). Twelve principles for open innovation 2.0. Nature, 533(7603), 314-316. https://doi. org/10.1038/533314a

10. De Silva, M., Howells, J., \& Meyer, M. (2018). Innovation intermediaries and collaboration: Knowledgebased practices and internal value creation. Research Policy, 47(1), 70-87. https://doi.org/10.1016/j. respol.2017.09.011

11. De Zubielqui, G., Lindsay, N., Lindsay, W., \& Jones, J. (2019). Knowl- 
edge quality, innovation and firm performance: a study of knowledge transfer in SMEs. Small Business Economics, 53(1), 145-164. https:// doi.org/10.1007/s11187-018-0046-0

12. Fernández-Sastre, J., \& ReyesVintimilla, P. (2020). The influence of the regional context on firms' innovation patterns: evidence from Ecuador. Technology Analysis \& Strategic Management, 32(5), 503515. https://doi.org/10.1080/095373 25.2019.1671586

13. Fischer, S., \& Sahay, R. (2000). The transition economies after ten years (Working Paper No. 7664). National Bureau of Economic Research. Retrieved from https://www.nber. org/system/files/working_papers/ w7664/w7664.pdf

14. Grover, V., \& Kohli, R. (2012). Co-creating IT value: New capabilities and metrics for multifirm environments. MIS Quarterly, 36(1), 225-232. https://doi. org/10.2307/41410415

15. Gupta, S., \& Malhotra, N. (2013). Marketing innovation: a resourcebased view of international and local firms. Marketing Intelligence \& Planning, 31(2), 111-126. https://doi. org/10.1108/02634501311312026

16. Gupta, S., Malhotra, N., Czinkota, M., \& Foroudi, P. (2016). Marketing innovation: A consequence of competitiveness. Journal of Business Research, 69(12), 56715681. https://doi.org/10.1016/j. jbusres.2016.02.042

17. Gyamfi, S., \& Stejskal, J. (2019a). Does External Knowledge Acquisition and Innovation Performance in Firms? (449 p.). Paper presented at 20th European Conference on Knowledge Management (ECKM). Academic Conferences and Publishing Limited. https://doi. org/10.34190/KM.19.241

18. Gyamfi, S., \& Stejskal, J. (2019b). University-industry cooperation and firm's knowledge absorptive capacity nexus. Paper presented at 11th International Conference on Education and New Learning Technologies. Retrieved from https://dk.upce. cz/handle/10195/75078

19. Hair, J., Hollingsworth, C., Randolph, A., \& Chong, A. (2017). An updated and expanded assessment of PLS-SEM in information systems research. Industrial Management \& Data Systems, 117(3), 442-458. https://doi.org/10.1108/IMDS-042016-0130

20. Hair, J., Hult, G., Ringle, C., \& Sarstedt, M. (2017). A Primer on Partial Least Squares Structural Equation Modeling (PLS-SEM). Retrieved from https://us.sagepub. com/en-us/nam/a-primer-on-partial-least-squares-structural-equation-modeling-pls-sem/book244583

21. Halásková, M., \& Bednář, P. (2018). Public research and development in European Union countries evaluation based on selected indicators. Scientific papers of the University of Pardubice. Series D, Faculty of Economics and Administration, 26(43), 74-86.

22. Henseler, J., Hubona, G., \& Ray, P. (2016). Using PLS path modelling in new technology research: updated guidelines. Industrial Management \& Data Systems, 116(1), 2-20. https://doi.org/10.1108/IMDS-092015-0382

23. Henseler, J., Ringle, C., \& Sinkovics, R. (2009). The use of partial least squares path modelling in international marketing. In New challenges to international marketing. Emerald Group Publishing Limited. https://doi.org/10.1108/S14747979(2009)0000020014

24. Hudec, O. (2015). Visegrad countries and regions: Innovation performance and efficiency. Quality Innovation Prosperity, 19(2), 55-72. http://dx.doi.org/10.12776/qip. v19i2.593

25. Izsak, K., \& Radošević, S. (2017). EU research and innovation policies as factors of convergence or divergence after the crisis. Science and Public Policy, 44(2), 274-283. https:// doi.org/10.1093/scipol/scw063

26. Izsak, K., Markianidou, P., Lukach, R., \& Wastyn, A. (2013). The impact of the crisis on research and innovation policies (Study for the European Commission DG Research by Technopolis Group Belgium and Idea Consult) (95 p.). Retrieved from http://ec.europa.eu/research/ innovation-union/pdf/expertgroups/ERIAB_pb-Impact_of_financial_crisis.pdf

27. Jensen, M., Johnson, B., Lorenz, E., \& Lundvall, B. (2007). Forms of knowledge and modes of innovation. Research Policy, 36(5), 680-693. https://doi.org/10.1016/j. respol.2007.01.006

28. Klasová, S. (2018). The Role of Agglomeration Economies in the Employment Growth in the Knowledge Intensive Services. Scientific Papers of the University of Pardubice, Series D: Faculty of Economics and Administration, 25(42), 92-103. Retrieved from https://editorial.upce. cz/1804-8048/26/1/918

29. Kotkova Striteska, M., \& Prokop, V. (2020). Dynamic Innovation Strategy Model in Practice of Innovation Leaders and Followers in CEE Countries - A Prerequisite for Building Innovative Ecosystems. Sustainability, 12(9), 3918. https:// doi.org/10.3390/su12093918

30. Kozena, M., Striteska, M., \& Svoboda, O. (2011). Dynamic balanced scorecard: model for sustainable regional development. Wseas Transactions on Environment and Development, 7(7), 211-221.

31. Krammer, S. (2009). Drivers of national innovation in transition: Evidence from a panel of Eastern European countries. Research Policy, 38(5), 845-860. https://doi. org/10.1016/j.respol.2009.01.022

32. Lee, V., Foo, A., Leong, L., \& Ooi, K. (2016). Can competitive advantage be achieved through knowledge management? A case study on SMEs. Expert Systems with Applications, 65, 136-151. https://doi. org/10.1016/j.eswa.2016.08.042

33. Liu, C. (2018). Examining social capital, organizational learning and knowledge transfer in cultural and creative industries of practice. Tourism Management, 64, 258-270. https://doi.org/10.1016/j.tourman.2017.09.001

34. MacGregor, R. (2004). Factors associated with formal networking in regional small business: some findings from a study of Swedish SME's. Journal of Small Business and Enterprise Develop- 
ment, 11(1), 60-74. https://doi. org/10.1108/14626000410519100

35. Meričková, B., Štrangfeldová, J., Muthová, N., \& Štefanišinová, N. (2020). Performance Measurement in Education Public Services Based on the Value for Money Concept. Scientific Papers of the University of Pardubice, Series D: Faculty of Economics and Administration, 28(3), 1099. https://doi.org/10.46585/ sp28031099

36. Moura, D., Madeira, M., Duarte, F., Carvalho, J., \& Kahilana, O. (2019). Absorptive capacity and cooperation evidence in innovation from public policies for innovation. International Journal of Innovation Science, 11(1), 2-19. https://doi.org/10.1108/ IJIS-05-2017-0051

37. Mukherjee, D., Lahiri, S., Ash, S., \& Gaur, A. (2019). Search motives, local embeddedness, and knowledge outcomes in offshoring. Journal of Business Research, 103, 365-375. https://doi.org/10.1016/j. jbusres.2017.10.035

38. Prokop, V., Stejskal, J., \& Hudec, O. (2019). Collaboration for Innovation in Small CEE Countries. E+ $M$ Ekonomie a Management, 22(1), 130. https://doi.org/10.15240/ tul/001/2019-1-009

39. Radosevic, S. (2011). Science-industry links in Central and Eastern Europe and the Commonwealth of Independent States: conventional policy wisdom facing reality. Science and Public Policy, 38(5), 365-378. https://doi.org/10.3152/03023421 1X12924093660435

40. Rosdi, I., Noor, A., \& Fauzi, N. (2020). External knowledge acquisition and innovation in small and medium-sized enterprises. In Understanding Digital Industry: Proceedings of the Conference on Managing Digital Industry, Technology and Entrepreneurship (CoMDITE 2019) (400 p.). Routledge. https:// doi.org/10.1201/9780367814557-95

41. Santoro, G., Bresciani, S., \& Papa, A. (2020). Collaborative modes with cultural and creative industries and innovation performance: the moderating role of heterogeneous sources of knowledge and absorptive capacity. Technovation, 92-93, 102040. https://doi.org/10.1016/j. technovation.2018.06.003
42. Santoro, G., Ferraris, A., Giacosa, E., \& Giovando, G. (2018). How SMEs engage in open innovation: a survey. Journal of the Knowledge Economy, 9(2), 561-574. https://doi. org/10.1007/s13132-015-0350-8

43. Srholec, M., \& Žížalová, P. (2014). Mapping the geography of R\&D: What can we learn for regional innovation policy in the Czech Republic and beyond? European Planning Studies, 22(9), 1862-1878. https://doi.org/10.1080/09654313.2 013.806435

44. Stejskal, J., Hajek, P., \& Prokop, V. (2018). Collaboration and innovation models in information and communication creative industriesThe case of Germany. Journal of Information and Communication Technology, 17(2), 191-208. https:// doi.org/10.32890/jict2018.17.2.2

45. Strelcová, S., \& Janasová, D. (2018). Clustering small and medium enterprises in the transport industry. Scientific papers of the University of Pardubice. Series D, Faculty of Economics and Administration, 25(42), 200-210. Retrieved from https:// dk.upce.cz/handle/10195/70523

46. Stř́teská, M., Zapletal, D., \& Jelínková, L. (2016). Performance management systems in Czech companies: findings from a questionnaire survey. E a M: Ekonomie a Management, 19(4), 44-55. https:// doi.org/10.15240/tul/001/2016-4004

47. Svetina, A., \& Prodan, I. (2008). How internal and external sources of knowledge contribute to firms' innovation performance. Managing Global Transitions, 6(3), 277-299. Retrieved from http://www.fm-kp. si/zalozba/ISSN/1581-6311/6_277299.pdf

48. Tödtling, F., \& Trippl, M. (2016). How do firms acquire knowledge in different sectoral and regional contexts? In R. Shearmu, Ch. Carrincazeaux, \& D. Doloreux (Eds.), Handbook on the Geographies of Innovation. Edward Elgar Publishing. https://doi.org /10.4337/9781784710774.00017

49. Toth, J., Torok, A., \& Balogh, J. (2018). Networking theory of innovation in practice. A Pan-European overview based on the Community
Innovation Survey. Paper presented at International Association of Agricultural Economists 2018 Conference, July 28-August 2, 2018, Vancouver, British Columbia. http://dx.doi.org/10.22004/ ag.econ. 277158

50. Trippl, M., Grillitsch, M., \& Isaksen, A. (2018). Exogenous sources of regional industrial change: Attraction and absorption of non-local knowledge for new path development. Progress in Human Geography, 42(5), 687-705. https://doi. org/10.1177\%2F0309132517700982

51. Tsouri, M. (2019). Knowledge transfer in time of crisis: evidence from the Trentino region. Industry and Innovation, 26(7), 820-842. https://doi.org/10.1080/13662716.2 018.1551124

52. Tu, C., Hwang, S., \& Wong, J. (2014). How does cooperation affect innovation in micro-enterprises? Management Decision, 52(8), 1390-1409. https://doi.org/10.1108/ MD-07-2013-0388

53. Vicente-Saez, R., Gustafsson, R., \& van den Brande, L. (2020). The dawn of an open exploration era: Emergent principles and practices of open science and innovation of university research teams in a digital world. Technological Forecasting and Social Change, 156. https://doi. org/10.1016/j.techfore.2020.120037

54. Von Delft, S., Kortmann, S., Gelhard, C., \& Pisani, N. (2019). Leveraging global sources of knowledge for business model innovation. Long Range Planning, 52(5). https:// doi.org/10.1016/j.lrp.2018.08.003

55. Zawojska, A. (2010). Determinants of farmers' trust in government agricultural agencies in Poland. Agricultural Economics, 56(6), 266-283. Retrieved from https:// www.agriculturejournals.cz/publicFiles/22389.pdf

56. Zdražil, P., \& Kozuń-Cieślak, G. (2017). The role of cross-border cooperation initiatives in respect of regional development: case study of Euroregion Neisse. Scientific papers of the University of Pardubice. Series D, Faculty of Economics and Administration, 25(2). Retrieved from https://dk.upce.cz/handle/10195/67942 